\title{
CONTEMPORARY THEMES IN DEBTOR REHABILITATION
}

\author{
David Milman, Centre for Law and Business, University of \\ Manchester. ${ }^{1}$
}

\section{INTRODUCTION:}

\section{Modern History Of Debtor Rehabilitation In Summary}

Prior to the early 1980s insolvency was used as a synonym for either liquidation or bankruptcy. Once a debtor had crossed the Rubicon into that economic condition known as insolvency the assumption was that the condition was terminal and the proper function of the law was to ensure a decent burial. As a result of the endeavours of the Cork Committee ${ }^{2}$ this pessimistic view of the situation has now changed; insolvency, like cancer, is no longer seen as a terminal illness but rather an opportunity to reassess debtor behaviour. Thus the 1985 reforms $^{3}$ saw the introduction into Great Britain of two dedicated corporate rescue procedures - company voluntary arrangements and administration orders. In terms of personal insolvency the individual voluntary arrangement was held out as an alternative to bankruptcy (or sequestration in Scotland). As insolvency lawyers we all now take the notion of debtor rehabilitation for granted. We have not yet persuaded ourselves that rehabilitation is the only game in town, but it remains a major attraction. In the 20 years since the Cork Report ${ }^{4}$ was published there has been a period in which the major reforms introduced in 1985 have been allowed to bed down and to develop organically. Indeed, the novel 1985 debtor rehabilitation procedure of administration was extended to banks by the Banks (Administration Proceedings) Order 19895. A similar strategy was pursued with regard to insolvent partnerships ${ }^{6}$ and in the near future the facility of administration will be made available to insurance

1 This article represents an expanded and modified version of a paper delivered to the Insolvency Lawyers' Association Annual Conference at Baildon Hall, West Yorks, on March 10 2001. Thanks are due to David Capper for his helpful comments. The usual disclaimer applies.

2 Cmnd 8558, 1982.

${ }^{3}$ These reforms did not become effective in Northern Ireland until 1991 when the Insolvency (Northern Ireland) Order 1989 (SI 1989/2405, NI 19) (hereafter the "1989 Order") came into force. For background see I. Fletcher, "The Insolvency of Individuals: An Outline of the Law of Bankruptcy under the Insolvency (Northern Ireland) Order 1989" (1991) 42 NILQ 293, D. Milman, "The Administration Order Regime: Corporate Rescue Crosses the Water" (1992) 43 NILQ 126.

4 Op cit $\mathrm{n} 2$.

5 SI 1989/1276. For Northern Ireland see the Banks (Administration Proceedings) Order (NI) 1991 (SR 1991/365).

${ }^{6}$ SI $1994 / 2421$ - the Northern Irish equivalent is to be found in the Insolvent Partnerships Order (NI) 1995 (SR 1995/225). 
companies, ${ }^{7}$ once the powers pursuant to section 360 of the Financial Services and Markets Act 2000 are exercised. The newest form of business organisation structure, the limited liability partnership, has had debtor rehabilitation procedures incorporated into the model from its inception in April $2001^{8}$. In addition to these formal, legally sanctioned, structures, there are informal procedures operating in the City of London characterised as the London Approach'.

The provision of structures (whether they be formal or informal) in which the turnaround game can be played is but one part of the picture. Structures will only be effective if the players are induced to operate within their parameters. The 1985 reforms certainly acknowledged this reality, particularly in the corporate sphere where directors of struggling companies were subjected to the new potential sanctions of wrongful trading and disqualification if they continued to trade an insolvent business instead of having recourse to officially sanctioned rehabilitation models ${ }^{10}$. Creditors must also be encouraged to play ball. The tax authorities added impetus to the debtor recovery strategy by removing in Finance Act 1994 section 144 fiscal disincentives to the release of bad debts. The banking community has expressed its broad adherence to rehabilitation philosophy in the Banking Code Statement of Principles ${ }^{11}$ where there is a commitment to support those rescue proposals which the banks believe have a reasonable prospect of succeeding.

There have on occasions been major perturbations in the advance of the corporate rescue bandwagon (witness the high profile Paramount affair ${ }^{12}$, resulting in the hasty enactment of the Insolvency Act 1994, a short but retrospective statute ${ }^{13}$ ) but for the most part we have adopted a "wait and

7 At present insurance companies in financial difficulty have to make do with schemes of arrangement or in some cases provisional liquidation as a way out of their difficulties - see N. Montgomery and G. Moss, "In the Long Run Off: Recent Developments in Insurance Insolvency" [2000] 13 Ins Intell 65.

8 Limited liability partnerships were introduced into Great Britain by an Act of that name in 2000. That legislation does not as a rule extend to Northern Ireland.

9 See Pen Kent, "The London Approach" (1993) 33 Bank of Eng Quart 110; P. Brierley "The Bank of England and The London Approach" [1999] (June) Recovery 12; J. Armour and S. Deakin, "Norms in Private Bankruptcy: The London Approach to the Resolution of Financial Distress" (2001) 1 Jo of Corp Studs 21.

10 This is a version of the well known strategy of stick and carrot. This explicit legislative provision on wrongful trading reflects developments in common law jurisprudence on the duty of care owed by directors of distressed companies to creditors at large. See generally D. Milman, "Personal Liability and Disqualification of Directors" (1992) 43 NILQ 1.

11 For a review of this Code see L. Otty, "Banks and Businesses: Working Together" [1997] (December) Insolvency Practitioner 26.

12 The case reached the House of Lords sub nomine Powdrill v Watson [1995] 2 AC 394. For background discussion see J. Lawless, "Paramount 3 and Leyland DAF - The Story So Far (and What Next)" [1994] (October) Ins Law 2; D. Pollard, "Adopted Employees in Insolvency: Orphans No More" (1995) 24 ILJ 141.

13 The government refused to extend this retrospectivity beyond a matter of days or to apply the legislation to non-administrative receivers - DTI Press Notices $\mathrm{P} / 95 / 282$ and P/94/319. On this legislation see P. Mudd "Insolvency Act 1994 Paramount Cured?" (1994) 10 IL \& P 38. The Insolvency Act 1994 does apply in 
see" attitude. The 1985-86 reforms have been given an opportunity to prove themselves and the courts on the whole have been supportive in trying to ensure that these new regimes operate in an effective manner that is consistent with legal principle ${ }^{14}$.

Turning to policy discourse, there have been attempts by the DTI/ Insolvency Service (illustrated by the incremental Consultative Documents of 1993, 1995 and 1999) ${ }^{15}$ and by the independent forum JUSTICE ${ }^{16}$ to generate some fundamental debate about the most effective way forward, but until recently this has produced few dividends in terms of solid reform.

On the front-line, debtor rehabilitation has achieved real statistical success in the personal insolvency context, but the figures on the corporate insolvency side appear at face value to be less impressive. Thus for the year 1999 IVAs made up nearly $25 \%$ of all personal insolvencies; on the corporate front the combined aggregate for CVAs and administration orders represented about $6 \%$ of the total number of corporate collapses ${ }^{17}$. The reasons for this relatively disappointing performance are unclear; it may be linked to technical deficiencies in the available models or due to the fact that the concept of a "fresh start" carries different connotations in the corporate context where the Phoenix syndrome (in the non-pejorative sense) is permitted through ease of access to newly incorporated companies. The past year or so has seen the relative quietude challenged both in cases coming before the courts, through legislation and in radical policy documents. In this paper I shall try to identify some common themes which now appear to be dominant in the discourse on debtor rehabilitation.

\section{Maximising Choice - Or Complicating Matters?}

English law offers a wide range of options for a debtor facing financial difficulties or for the creditors of such a debtor. There is no pursuit of the "one size fits all" goal. In many senses this choice of menu is more extensive than that on offer in comparable jurisdictions; it is difficult to argue on grounds of principle with choice but it must not be assumed that it is always a good thing. Thus, as a result of the 1985 reforms there were at least four regimes on offer for a distressed personal debtor, though in reality

Northern Ireland as section 4 (introducing schedule 1) amends the relevant legislation in the 1989 Order.

14 See D. Milman, "The Administration Order Regime and the Courts" at 369 in Insolvency Law: Theory and Practice (ed. H. Rajak, 1993) based upon the Hart workshop in 1992. Note also D. Prentice, F. Oditah and N. Segal, "Administration: The Insolvency Act 1986 Part II" [1994] LMCLQ 487. In Northern Ireland, although the jurisprudence is less extensive, there are signs of a more circumspect approach on the part of the judiciary - see D. Capper, "Administration in Northern Ireland" [1999] Ins Law 283.

15 For a summary of the 1993 and 1995 proposals see D. Milman and D. Mond Security and Corporate Rescue (1999) at 44-46. The 1999 proposals are discussed by the author in "Insolvency Law Reform Revisited (Again)" [1999] (10) Palmer's In Company 1.

16 Insolvency Law: An Agenda for Reform, 1994. Discussed by S. Rajani, "JUSTICE Committee Report on Insolvency Law Reform" (1995) 11 IL \& P 24.

17 For these statistics see 1999 Insolvency General Annual Report - summarised in DTI Press Notice P/2000/513. 
in English law ${ }^{18}$ the choice is narrowed to two: i.e. bankruptcy ${ }^{19}$ and IVA $^{20}$. A similar range of options was presented to the corporate debtor looking for a second chance ${ }^{21}$.

One option for a distressed company is to exploit the CVA procedure ${ }^{22}$. The courts have been inclined to support freedom of choice and not to adopt a paternalistic approach when faced with turnaround proposals featuring a CVA. This laissez faire strategy was exemplified by IRC $\mathrm{v}$ Adam \& Partners $L t d^{23}$ where the Court of Appeal gave the green light to a proposed CVA that apparently offered no return to unsecured creditors. The problem in this case was that the Revenue felt that it was disadvantaged by the terms of a CVA which had been agreed by the required majority of creditors. Unfortunately the time for a direct challenge to the arrangement (pursuant to section 6 of the Insolvency Act 1986) had elapsed and therefore the Revenue fell back on the argument that what had been agreed did not fall within the terms of section 1 of the Insolvency Act 1986. Although this technically could not be viewed as a "composition" within the meaning of section 1 of the Insolvency Act 1986 as it offered no distribution to creditors, it might qualify as a "scheme of arrangement" in that it provided for a moratorium on debt repayment. Clearly the court was not minded to let technicalities stand in the way of a proposal that the unsecured creditors had approved by "democratic decision" and was certainly not prepared to investigate the motives behind voting behaviour. As may be inferred from the comments of Mummery $\mathrm{LJ}^{24}$ there was no legislative authority for such a questioning approach towards the decision of a proper majority. Had the case fallen within the unfair prejudice jurisdiction the court would have been compelled to undertake a more rigorous scrutiny.

18 In English law the deed of arrangement is moribund and the county court administration order has not been allowed to fulfil its full potential because of a failure to put into effect reforms enacted in 1990. It is hardly surprising that the government is looking again at this latter flaw in the system of dealing with personal debt, see $\mathrm{Cm} 5052$ at para 5.12. In Northern Ireland deeds of arrangement are governed by arts 209-225 of the 1989 Order. IVAs in Northern Ireland are regulated by arts 226-237 of the 1989 Order.

19 A debtor in distress often views bankruptcy as an easy way out of difficulties because after 3 years debts are wiped out. This option of falling on one's own sword has been available since the early 19th century and it is increasingly popular, so much so that some debtors have tried to argue (unsuccessfully) that there is a fundamental right to be bankrupted without requiring payment of the deposit fee - see $R$ v Lord Chancellor, ex parte Lightfoot [2000] QB 597.

20 For an illuminating discussion of the fundamentals of the voluntary arrangement see P. Walton, "Voluntary Arrangements: The Nature of the Beast" [1997-98] 3 $R A L Q 277$.

${ }^{21}$ One contested issue is whether receivership can be viewed as a rescue regime proper - see G. McCormack, "Receiverships and the Rescue Culture", [2000] CfiLR 229 for discussion of this matter. For empirical research see R. Hamilton, B. Howcroft, K. Pond, K and Z. Liu, "Back from the Dead - Survival Potential in Administrative Receivership" (1997) 13 IL \& P 78.

22 Insolvency Act 1986 ss 1-7. The Northern Irish equivalent is to be found in arts 14-20 of the 1989 Order.

23 [2000] BPIR 986.

24 Ibid at 995 . 
However, the courts do not have the power to permit rehabilitation procedures where the legislation offers no such option on the menu card. Thus in Fletcher $\mathrm{v} \operatorname{Vooght}^{25}$ Lloyd $\mathrm{J}$ was not inclined to validate an Individual Voluntary Arrangement (IVA) which by oversight (and for reasons which are not entirely clear) had proceeded successfully without the prerequisite of a section 252 interim order ${ }^{26}$. This was not fatal to the proposed arrangement because the great majority of the creditors appeared to be in a supportive mood. When the oversight was discovered (some four years later) the supervisor (who only became involved in the case after the creditors had voted for the arrangement) took the view that the IVA was not valid for this reason and an attempt by the debtor (who appears to have fulfilled his obligations under the "IVA") to challenge this analysis met with no joy in the court. Lloyd J, after meticulous scrutiny of the legislative framework, took the view that the interim order and IVA were "interdependent" in the eyes of the statutory scheme. In particular, the court could not grant a retrospective interim order to tidy matters up. The possibility of estoppel by convention was left open for further argument. There is no doubt that this inconvenient conclusion was reached with regret and the learned judge suggested that the drafting of the legislation could be improved. As we shall see that hint has been followed up by the powers that be.

Similarly in Wright v Official Receiver ${ }^{27}$ District Judge Caddick (sitting in the Medway County Court) refused to permit a discharged bankrupt to make use of an IVA procedure to maximise returns to creditors. Here the bankrupt, after obtaining her discharge from bankruptcy, had acquired an unexpected windfall as a result of a sharp rise in property prices; this addition to the estate was sufficient to enable her to repay her creditors and she wished to do this through the mechanism of an IVA rather than by the trustee in bankruptcy administering the distribution. The debtor felt that this would lead to a more efficient return than that upon bankruptcy administration and could produce a surplus for the benefit of the debtor. The legislative scheme of things did not envisage such a possibility because once the bankrupt had obtained her discharge she could not be a debtor in respect of released debts for the purposes of the IVA scheme.

The Insolvency Act 2000 will, of course, further extend the turnaround possibilities on offer ${ }^{28}$. As far as the Company Voluntary Arrangement (CVA) procedure is concerned we have witnessed the advent of the long awaited CVA cum moratorium, which is available through the filing of a notice with the court; no court order is required. The detailed rules for this model are mapped out in considerable depth in Schedule A1 of the Act. This offering is only extended to small (as defined by section 247 of the Companies Act 1985) "eligible" companies. It should of course be noted

25 [2000] BPIR 435.

26 In Northern Ireland that is an order under art 226 of the 1989 Order.

27 [2001] BPIR 196. The key to understanding this case is that discharge does not bring to an end the trustee's powers and responsibilities with regard to payment of debts. Discharge merely frees the bankrupt of certain obligations and disabilities.

28 For discussion of this legislation see A. Smith and M. Neill, "The Insolvency Act 2000" (2001) 17 IL \& $P$ 84. As far as Northern Ireland is concerned the Insolvency Act 2000 does not apply. 
that the 28 day moratorium on offer here is an optional extra; old-style CVAs are still possible for all types of company where a moratorium is deemed not to be necessary, for example where the creditors appear cooperative.

Another extension to choice under the 2000 Act is provided for by section 3 (introducing Schedule 3) which permits individual voluntary arrangements to be undertaken without the need for a preliminary interim order pursuant to section 252. This is a sensible and cost effective move that might combat difficulties similar to those in Fletcher v Vooght ${ }^{29}$. The change, however, is not retrospective.

There is no indication that we have reached the limitations of this strategy of promoting diversity in terms of rehabilitation models. Thus the controversial Insolvency Service consultative document Bankruptcy - A Fresh Start (April $2000)^{30}$ floats in paragraph 79 the idea of a "post bankruptcy IVA". This hybrid creature seems designed to deal with problems caused by flaws in the income payments order regime operated under Insolvency Act 1986 section $310^{31}$. It is an interesting concept, but surely it would be more logical to address the failings of the IPO system instead of adding a new layer of jurisdictional complexity. Some of the more vexed legal disputes arise on the interface between concurrent or consecutive insolvency regimes. For example, what happens to a voluntary arrangement and funds collected thereunder where there is a subsequent liquidation or bankruptcy? Invariably these thorny points are left to the courts to resolve with minimal assistance from the legislature, possibly because the draftsmen did not want to contemplate such negative outcomes ${ }^{32}$.

Another difficulty with this choice maximisation strategy is that it increases the complexity of the law and can throw up unforeseen difficulties for debtors and their professional advisers. Investigation of options has an economic cost. It is not always clear as to the best way forward and advisers who recommend an approach that turns out to be unsuccessful might in future face claims alleging negligent advice. Perhaps one way of dealing with this maze is to go down the route of a single "gateway" under which choices can be properly evaluated and sanctioned by the court. However, this gateway idea, which might increase short term costs, attracted mixed comments from the Insolvency Service Review Group in A Review of Corporate Rescue and Business_Reconstruction Mechanisms ${ }^{33}$. The Review Group was not in favour of the idea in the context of all insolvent companies, especially where the business had already ceased, but felt it had some merit

29 [2000] BPIR 435.

30 April 2000 - criticised by C. Haig, "Removing the Stigma from Bankruptcy - Or Just Making it Worse?" [2000] (June) Recovery 16; R. Robinson, "Bankruptcy - A Fresh Start?" [2000] (August) Recovery 31; V.S. Dennis, "Bankruptcy Reform - A Start in the Wrong Direction?" (2000) 16 IL \& P 179.

31 Art 283 of the 1989 Order.

32 For discussion of how the courts have developed a pragmatic body of jurisprudence see E. Bailey, "The Effect of a Bankruptcy Order on an Individual Voluntary Arrangement" [1995-96] 2 RALQ 87; J. Middleton, "The Effect of Subsequent Bankruptcy upon an Individual Voluntary Arrangement" [1998] (May) Insolvency Practitioner 24.

33 November 2000 - see D. Milman, "Corporate Rescue - Reform and Prospects for Reform” [2001] (1) Palmer's In Company 1. 
for trading companies where a revised form of administration order procedure might be exploited.

At the end of the day we reiterate that it is difficult to argue against the extension of choice. But we must avoid the trap of believing that all distressed debtors are capable of rehabilitation if only an appropriate model can be devised. All the evidence suggests that only a minority of debtors are capable of benefiting from rescue procedures. This is because in many cases the financial predicament is largely the responsibility of the debtor (or the managers of the debtor corporation) and without some form of re-education or counselling there is every likelihood of the situation recurring. It would be in the interests of all concerned to recognise that unpalatable fact and abandon the increasingly desperate search for novel rescue procedures. The law of diminishing returns must be borne in mind.

\section{Transparency And Probity: A Lesson For All Players In The Rehabilitation Game}

If the debtor rehabilitation strategy is to work the relevant procedures must appear to be above suspicion. We must not allow the impression to be created that it is a soft touch for irresponsible debtors or an additional income stream for insolvency practitioners. This imperative is particularly important in an age when professional practices are increasingly coming under the microscope ${ }^{34}$.

Mechanisms have long been in place to achieve this goal of promoting responsible usage of the available procedures. Thus, under section 276 of the Insolvency Act $1986^{35}$ a supervisor of an IVA can present a default petition seeking the bankruptcy of a debtor if there have been material misrepresentations in statements of affairs or other documents or the debtor has failed to comply with commitments undertaken as part of the arrangement. The significance of this provision was stressed by Rimer $\mathbf{J}$ in Re Tack: ${ }^{36}$

"a debtor who persuades his creditors to agree to an IVA as an alternative to bankruptcy enjoys considerable advantages over

34 The courts have historically played a role in promoting ethical standards amongst insolvency practitioners - witness the curious rule in Ex parte James (1874) $9 \mathrm{Ch}$ App 609 which requires those practitioners who are officers of the court to act honourably. The OFT has recently completed a review of the professions - for background see The Times March 8 2001. The courts are increasingly scrutinising insolvency practitioner remuneration packages, particularly in determining whether a voluntary arrangement is viable.

35 Art 250 of the 1989 Order. On such a supervisor's petition the court retains the discretion to make a bankruptcy order even if the default (usually non payment of sums due) has been rectified when the petition is heard. No such order could be made in similar circumstances on a simple creditor petition. On this curiosity (which is justifiable on grounds of protecting the integrity of the VA process) see Carter-Knight $\mathrm{v}$ Peat [2000] BPIR 968. A CVA supervisor has a statutory power to petition for administration or winding up (IA 1986 s. 7(4)(b)/Art 20(4)(b) 1989 Order) and it is common to find in CVA documentation this power being converted into an obligation to petition for compulsory winding up in certain defined circumstances.

36 [2000] BPIR 164 at 206. 
a debtor against whom a bankruptcy order is made. If, however, a debtor who does so persuade his creditors is then shown to have misled them in a material way, he ought to have a bankruptcy order made against him".

In this particular case the culmination of errors in the information provided by the debtor were sufficient to persuade the court that a material irregularity had indeed arisen.

The courts have in recent months reasserted the need for voluntary arrangements to be put in place in a transparent manner. In Somji v Cadbury Schweppes ${ }^{37}$ a third party made confidential offers to certain strategic creditors to take assignments of their debts on favourable terms if they supported the proposed arrangement. The debtor was alleged to have been aware of these negotiations but not to have disclosed this information to the creditors' meeting. The voluntary arrangement was approved and one creditor challenged it. The Court of Appeal declared that full information which was accurate up to the time of the creditors' meeting was an essential requirement of such a meeting. As Judge LJ emphasised, the Insolvency Act and the Rules:

"encapsulate the principles of transparency and good faith and make proposed secret deals or confidential arrangements of the kind referred to by Robert Walker LJ as unacceptable today as they were in Victorian England." 38

Another mechanism that can have an equally beneficial effect is to be found in fallback provisions such as sections 6, 27 and 262 of the Insolvency Act $1986^{39}$. These provisions allow for arrangements/actions of administrators to be challenged on the grounds that they unfairly prejudice the interests of a party or because there is evidence that a material irregularity has occurred ${ }^{40}$.

In addition to these formal controls it should always be borne in mind that social norms and professional imperatives can operate to regulate opportunistic behaviour both by debtors and practitioners. A debtor who has a poor track record in terms of fulfilling promises will be less likely to secure creditor support in the future. More importantly, practitioners specialising in turnaround work depend on winning the confidence of creditors in order to obtain their support for the less convincing debtor proposals. A weak practitioner who repeatedly allows debtors to renege on their promises will quickly find his or her market integrity compromised (possibly resulting in professional disciplinary action) and future income prospects damaged.

The latest debtor rehabilitation legislation echoes this imperative. The Insolvency Act 2000 thus creates an additional offence of procuring an IVA by false statements (see Schedule 3 paragraph 12, which inserts a new section 262A into the 1986 Act). Additional "whistle blowing" obligations

37 [2001] 1 WLR 615. For discussion see N. Griffiths, "Voluntary Arrangements after Somji" (2001) 17 IL \& P 104.

38 Ibid at 630

39 Respectively arts 19,39 and 236 of the 1989 Order

40 For key cases outlining the principles governing the exercise of this jurisdiction see Doorbar v Alltime Securities [1995] BCC 1149; Re A Debtor (No. 101 of 1999) [2001] 1 BCLC 54. 
are then imposed on the nominee and supervisor by a new section $262 \mathrm{~B}$. The legislature is thus anxious to avoid the impression that it is providing a soft touch to be abused by unscrupulous debtors.

Where the new style CVA is used the actions of the directors are to be closely supervised by the nominee. Thus under paragraph 24 of Schedule A1 of the Insolvency Act 2000 we find that the nominee must monitor the proposal to see that it has a reasonable prospect of being approved ${ }^{41}$ and to see that the company has sufficient funds to see it through the moratorium period. In fulfilling this monitoring role the nominee can rely upon information supplied by the directors, unless he has reason to doubt its accuracy. If this process of monitoring produces a negative conclusion the nominee must withdraw by virtue of the obligation imposed by paragraph 25 . These control mechanisms are seen as particularly important means to deter opportunistic behaviour by company directors seeking to use the moratorium to play for time without having any serious intention to formulate rescue proposals.

Looking further afield the Insolvency Service Report on Company Rescue and Business Reconstruction Mechanisms (November 2000) has urged both the financial institutions and the insolvency profession to revisit their codes of conduct and ethical statements to ensure that the controversial practice whereby investigating accountants recommend receiverships with the appointment invariably being taken up by a partner in the same firm does not bring the institution of receivership into disrepute ${ }^{42}$. The Working Party seems to have reached this conclusion on the basis that the "problem" may be more apparent than real; in other words there is a genuine difficulty with public perceptions of the practice even though those perceptions may not be supported by hard evidence ${ }^{43}$. From the viewpoint of this commentator the proposed solution represents a weak response; it would be much simpler to prohibit the practice altogether. Because of the nature of the accountancy/ insolvency profession there would be no net loss of business to the profession as a whole and a considerable enhancement in the image of the profession would accrue.

\section{Collectivism: Utilitarianism At Work}

One rationale for encouraging rehabilitation procedures is that the strategy can underpin the idea of collectivism in insolvency law by offering better rewards for unsecured creditors and compelling powerful interest groups to stay their hand in the common good. The need for this is apparent to all when one reflects upon the appalling returns for unsecured creditors under any conventional liquidation, receivership or bankruptcy. These have got no

41 The legislation here is building on the case law which has directed the nominee to consider the question of viability - see Cooper v Fearnley [1997] BPIR 20; Greystoke v Hamilton-Smith [1997] BPIR 24; Hook v Jewson Ltd [1997] BCC 752; and Knowles v Coutts \& Co [1998] BPIR 96.

42 For research on this practice see A Katz and M Mumford, "Receivership Following Investigation" (1999) 15 IL \& P 135.

43 See para 121. 
better in recent years; indeed the plight of the unsecured creditors has become increasingly marginalised ${ }^{44}$.

This trade off between parochial property rights and the common good has always been a feature of rehabilitation procedures since they were introduced. Thus, the administration order mechanism for companies and the IVA regime included a moratorium on hostile enforcement actions as a key working component (see IA 1986 sections 10 and $11^{45}$ ). The courts have for the most part done their utmost to maximise the protective shield triggered on administration. A rare exception to this policy was found in the early case of Air Ecosse v Civil Aviation Authority ${ }^{46}$ where a procedure to revoke an operating licence was held by the Court of Session in Scotland to fall outside the moratorium. In contrast, the dominant and protective attitude, which has subsequently become the norm with the judiciary, is attested to by the judgment of Ferris $\mathrm{J}$ in Re Axis Genetics plc ${ }^{47}$ (a case involving an application by a business competitor to revoke a European patent granted to a company now in administration) where the moratorium on "proceedings" was interpreted in such a way as to cover any type of civil proceedings (whether judicial or quasi-judicial), and not merely those connected with debt enforcement. This interpretation is surely justified when one takes into account the purpose of the moratorium. Similarly, it is clear that criminal proceedings may fall within the ambit of this particular moratorium, as the Court of Appeal accepted in Environment Agency v Clark $^{48}$. Having said that, the court enjoys the power to allow a prosecution to proceed by granting leave, which it should do if the public interest demands. One consequence of these recent rulings is that Air Ecosse ${ }^{49}$ is now of dubious authority, as least as far as English law is concerned.

The Insolvency Act 2000 has bolstered the spirit of collectivism by introducing an optional moratorium for CVAs embarked upon by "eligible" small companies (as defined by paragraphs 2-4 of Schedule A1 which in turn make use of the criteria laid down in section 247(3) of the Companies Act 1985). This reform appears to represent a cautious "toe in the water" and the expectation is that the mechanism will become more widely available in the years to come. This, of course, was the experience with administration Mark I. The Secretary of State has been given power to modify the catchment area.

A significant feature of the introduction of the new CVA moratorium is that it cannot be defeated by means of a provision in a floating charge providing for crystallisation on the commencement of the moratorium or on the mere taking of steps to obtain such a moratorium (see Insolvency Act 2000, Schedule A1 paragraph 43). This is yet another significant indicator of how

44 See JUSTICE, Insolvency Law: An Agenda for Reform (1994) at para 5.2.

45 Arts 23 and 24 of the 1989 Order.

46 (1987) 3 BCC 492.

47 [2000] BCC 943.

48 [2000] BCC 653 - discussed by C Abbot, "Expanding Environmental Accountability: Administration and the Requirement of Leave to Commence Criminal Prosecutions" [2001] Ins Law 114.

49 Op cit $\mathrm{n} 46$ 
established property entitlements and the notion of freedom of contract in defining security rights are being sacrificed to the common good.

Existing moratorium models have been firmed up by the inclusion of traditional rights of landlords to forfeit leases and to levy distress in both the administration order and IVA models. The problem here in the past has been the refusal of the courts to equate the right of forfeiture to an enforcement of security. This general approach is reflected by the bankruptcy case of Razzaq v Pala ${ }^{50}$. Whatever the strict position may be it was a clear oversight on the part of the legislators to overlook the need to protect security of tenure of business premises when formulating the moratorium deemed necessary for debtor rehabilitation. Parliament has now resolved the conundrum by explicit provision. This is an immediate fruit of the November 2000 Insolvency Service Report that was introduced as a late amendment into the Insolvency Act 2000. As far as administration orders are concerned, the landlord's right to forfeit and re-enter is now specifically covered by the moratorium as a result of the enactment of section 9 of the 2000 Act. Thus, we return to the position favoured by Harman $\mathrm{J}$ in Exchange Travel Agency $\mathrm{v}$ Triton Property Trust ${ }^{51}$, a view that was very much in the minority, a fact attested to by later decisions such as that of Neuberger J in Re Lomax Leisure $L t d^{52}$. In cases of IVAs the interim order made under section 252 of the Act now encompasses both forfeiture and distress. Thus, inconvenient authorities such as McMullen \& Sons Ltd v Cerrone ${ }^{53}$ are no longer good law on these points. These new aspects of the moratorium have also been included in the new CVA model de novo. One beneficial consequence of the reforms with regard to distress is the harmonisation of corporate and personal insolvency laws on this question; a welcome rationalisation. Distress has always fallen within the administration moratorium by virtue of the explicit provisions in Insolvency Act 1986 sections 10(1)(c) and 11(3)(d) $)^{54}$.

Preferential creditors have (not surprisingly) survived the "ravages" of utilitarianism under English law. Apparently the Exchequer stands to lose a modest £60-90 million per annum if preferential debts are abolished. Instead, their role and status on debtor rehabilitation from the start of the new tax year is to be made the subject of bureaucratic imperative to act "sensitively" and not to rely on their statutory powers to block rescues unless preferential debts are fully catered for. Some details of this new initiative are to be found in DTI and Customs and Excise Press Notices ${ }^{55}$. It now seems

50 [1997] 1 WLR 1336.

51 [1991] BCLC 396. See D. Milman and M. Davey, "Debtor Rehabilitation: Implications for the Landlord-Tenant Relationship" [1996] JBL 541.

52 [1999] 2 BCLC 126 - discussed by P. Shaw, "Administration: Peaceable Re-Entry by a Landlord Revisited" [1999] Ins Law 254.

53 [1994] BCC 25.

54 The long term future of the remedy of distress is in doubt and the Lord Chancellor's Department is currently conducting a major review which proposes significant modifications in the future operation of the distress remedy - see Lord Chancellor's Department Consultation Paper Enforcement Review Consultation Paper No. 5 (May 2001). Distress for rent and rates was abolished in Northern Ireland by Judgments (Enforcement) Act (NI) 1969 s122.

55 See DTI Press Notice P/2000/727 and [2001] Simon's Weekly Tax Intelligence 165. The Voluntary Arrangements Service initiative has been extended to Northern Ireland - [2001] Simon's Weekly Tax Intelligence 626. 
likely that the revenue authorities will be more likely to offer support for arrangements even if there is no offer of a return of $100 \mathrm{p}$ in the pound. State creditors will be encouraged to take a "commercial" perspective and to recognise that the state might in the long term benefit from keeping a taxpayer afloat. We reserve judgement on whether this policy based on exhortation is the best way forward. Empirical research will prove vital here. Presumably, if the scheme does lead to better returns for taxpayers the arguments in favour of extending and formalising it will become more compelling in Treasury quarters. If the scheme fails to produce the expected reforms the wafer-thin arguments for preserving preferential status in this context will surely have been exhausted. Indeed recent events may have rendered this experiment in altering bureaucratic behaviour irrelevant. For, on June 18 2001, the Treasury announced ${ }^{56}$ that it was shortly to publish a White Paper which would recommend the abolition of preferential status for unpaid taxes. The future here then is one of considerable change.

This trend in favour of sacrificing sectarian interests in the common good is likely to be maintained in the future. The future of the floating charge holder's right of veto in cases of administration is open to question in the opinion of the Insolvency Service Report of November 200057. Research by Professor Harry Rajak which is cited at paragraph 71 by the Review Group indicates that this reform may not have as dramatic an impact as might first be thought; the evidence suggests that in some $50 \%$ of cases of administration this right of veto is not exercised. This may well be because banks feel adequately protected by the administration regime as it presently operates, though that feeling of security is always likely to evaporate if the law of administration develops in a manner that is deemed to be "unhelpful" to financial institutions. The rights conferred by fixed charges over future book debts are also likely to be circumscribed if one has read correctly the runes in this report ${ }^{58}$.

It should be apparent to any observer that evolution in this area has not been entirely rational. It is now even more difficult to see why preferential claims should be allowed to survive when other powerful lobbies (such as banks and property owners) have been compelled to surrender rights to promote rehabilitation. Having said that, it would be churlish to deny that progress is being made.

\section{Promoting Efficiency In Debtor Rehabilitation}

Research suggests that debtor rehabilitation provides a better rate of return for creditors than conventional insolvency outcomes. However, we must not be complacent and it is good to see that developments have occurred over the recent past which should reinforce that level of recovery performance.

56 HM Treasury Press Notice 67/01.

57 For a defence of traditional bank rights and a critique of these proposals see Editorial in (2000) 16 IL \& P 209.

58 See para 138. The recent ruling of the Privy Council in Agnew $v$ Revenue Commissioners (Re Brumark Investments Ltd) [2001] 3 WLR 454 is likely to further reduce their utility. 
The courts are alert to the need to promote the efficient operation of the rehabilitation regimes ${ }^{59}$. The many cases on administration exits show a real desire to promote an efficient conclusion to administration without doing violence to the language used in the statute. In a similar vein we may note cases such as $\operatorname{Re} T \& D$ Industries $p l c^{60}$ where Neuberger $\mathrm{J}$ went to great lengths to maximise the discretion enjoyed by administrators in making emergency disposals without requiring the leave of the court. As Neuberger J put it:

". . . the fewer applications which need to be made to the court the better . . Administration is meant to be a more flexible, cheaper and comparatively informal alternative, with a potentially less destructive result, than liquidation."61

Facilitation in similar circumstances, but by different means, was also very much to the fore in Re Harris Bus Co Ltd ${ }^{62}$, where Rattee $\mathrm{J}$ found a way of permitting creditor meetings to be summoned at short notice to sanction an emergency disposal by the administrator. Again in Cork v Rolph ${ }^{63}$, a less bureaucratic procedure for resigning insolvency office (including presumably appointments in respect of voluntary arrangements) was officially sanctioned by Neuberger J. Block advertisements in the London (or Belfast) Gazette could be utilised instead of the more costly method of holding numerous creditors' meetings or writing to individual creditors.

The performance of professional "repeat players" is a vital ingredient in securing operational efficiencies. It is likely in the wake of the comments of the Court of Appeal in Medforth $\mathrm{v}$ Blake ${ }^{64}$ that the courts will expect those insolvency practitioners handling rehabilitation cases to display standards of reasonable care (defined as "due diligence" by Sir Richard Scott VC). Similarly, in Harmony Carpets v Chaffin-Laird ${ }^{65}$ Rattee $\mathrm{J}$ indicated that the authorities established the proposition that the abiding legal requirement imposed on insolvency practitioners is to exercise critical professional judgement. Having said that, there is no role for the court in interfering with commercial judgements, a point reinforced by Neuberger $\mathrm{J}$ in $\operatorname{Re}$ C.E. King $L t d^{66}$. Equally, the courts are aware that no practitioner is in a position to underwrite the success of an arrangement. The comments of Owen $J$ in Heritage Joinery v Krasner ${ }^{67}$ are a clear (and welcome) indication of this realism on the part of the judiciary. Moreover, the importance of complainants having recourse to institutional grievance procedures (such as

59 Witness the Practice Note (Administration Order Applications: Independent Reports) [1994] BCLC 347.

60 [2000] BCC 956.

61 Ibid at 961 .

62 [2000] BCC 1151.

63 The Times December 212000.

64 [1999] 3 WLR 922. For discussion of this important authority, which will do much to restore integrity to the institution of receivership by undermining the much criticised Privy Council ruling in Downsview Nominees Ltd v First City Corporation Ltd [1993] AC 295, see S. Frisby, "Making a Silk Purse out of a Pig's Ear-Medforth v Blake" (2000) 63 MLR 413.

65 [2000] BPIR 61.

66 [2000] 2 BCLC 297.

67 [1999] BPIR 683. 
making use of a section 263 application ${ }^{68}$ ) rather than pursuing private law claims, was stressed by the Court of Appeal in King v Anthony ${ }^{69}$.

By allowing IVAs to be undertaken without the expense of an interim order the legislature is showing good awareness of the need to keep costs under control. A similar point could be made with regard to the new CVA procedure; a court order is not required under the new Insolvency Act to invoke the moratorium, merely the filing of documentation with the court (Schedule A1 paragraphs 7 and 8). This is an innovation in this area as far as English law is concerned.

New avenues for promoting cost effectiveness are being sought out. The November 2000 Insolvency Service Report also encourages administrators to make more use of the services of directors as part of an effort to reduce management costs (see paragraph 77). This may also encourage directors to have early recourse to administration; all the evidence indicates that prompt usage of rehabilitation procedures greatly enhances the prospects for success, though this economy might be counteracted by a realisation that management failure is often the major cause of corporate collapse.

But it is vital that mechanisms be in place to draw rehabilitation procedures to a speedy conclusion if the rescue strategy is not working. The Insolvency Act 2000 contains some important provisions here. Thus the nominee is specifically directed to "pull the plug" on the new CVA with moratorium if it becomes clear that the proposal is unlikely to attract creditor support if the finance is not in place to keep the business running in the interim (see Schedule A1 paragraph 25).

Insolvency practitioner fees and disbursements will represent one of the significant cost elements in any rehabilitation strategy ${ }^{70}$. The possible arrival of non-qualified insolvency practitioners (so-called turnaround experts) who may nevertheless be recognised by the authorities pursuant to section 4 of the Insolvency Act 2000 (which inserts a new section 389A into the 1986 Act) could serve to keep fees in check if there is a significant increase in the number of practitioners operating in the field and a corresponding enhancement of competition. Having said that, the fact that we are dealing with an insolvent estate and a recognition that we live in an age of increasing scrutiny already serves to promote that goal.

\section{Incentives: The Vital Component}

The debtor rehabilitation strategy will only make progress if appropriate incentives for debtors and creditors remain in place. At present there are clear attractions for unsecured creditors and debtors to go down the rehabilitation route. Maintaining the incentive for unsecured creditors to support voluntary arrangements is clearly a critical policy goal. The courts can help here by sensible interpretation of the terms of approved proposals,

68 Art 236 of the 1989 Order.

69 [1999] BPIR 73.

70 The remuneration/disbursements cost is of course greater for the smaller type of voluntary arrangement - see the data referred to by D. Flynn, "Individual Voluntary Arrangements" [2001] (July) Recovery 18. 
as occurred in Welsby $\mathrm{v}$ Brelec Installations Ltd $^{71}$ where the arrangement terms were construed by Blackburne $\mathrm{J}$ in such a pragmatic way as to maximise the freedom of manoeuvre of the supervisor and the protection extended to the participating creditors. Equally, participating creditor expectations as to how the CVA would be allowed to develop (and terminated if necessary) should be protected as far as possible, a point stressed by Peter Smith QC (sitting as a Deputy Judge in the Chancery Division) in Souster v Carman Construction Co Ltd ${ }^{72}$. Essentially, the courts have accepted the notion that voluntary arrangements are contracts ${ }^{73}$ and, provided third party interests are not prejudiced, the participants should be left to resolve difficulties themselves. This perception underpins the reasoning of the Court of Appeal in Raja v Rubin ${ }^{74}$, where Peter Gibson LJ characterised an IVA as a "multilateral contract". It is consistent with this philosophy that the courts will be reluctant to imply terms into an arrangement ${ }^{75}$.

As far as secured creditors are concerned, the position on incentives is more complicated. Secured creditors often lack the financial motivation to play the rehabilitation game because, in purely financial terms, their recovery prospects are equally good through using traditional insolvency procedures (such as receivership). However, there are other incentives beyond pure monetary returns which are capable of influencing financial institution behaviour. The well-being of clients is viewed as increasingly important in many organisations. There is also the growing trend towards all large businesses having in place a policy on corporate social responsibility. This has been apparent for many years in the willingness of banks to support rescue proposals in respect of failing football clubs; one cannot but suspect that a more sceptical attitude might have been taken for a less high profile local business which was encountering difficulties. If these influences fail, then the government can legislate to promote an appropriate response. There is clear evidence of this tendency tucked away in the provisions of the Insolvency Act 2000, particularly with regard to the rights of the floating charge holder on the CVA moratorium. Moreover, comments made in the November 2000 Insolvency Service Report also point to a continued erosion of secured creditor rights as being very much on the agenda. These indicators have been reinforced by an announcement made on June 182001 by HM Treasury that the government intends to publish a White Paper in

71 [2000] 2 BCLC 576. For a full discussion of this case see S.A. Frieze, "Who Gets the Funds when a VA Fails" [2000] 13 Ins Intell 69. The IVA case of Re Coath [2000] BPIR 981 is entirely consistent with this approach.

72 [2000] BPIR 371.

73 Pitt v Mond [2001] BPIR 624 at 632 per Judge Roger Cooke. For general discussion of this perception of voluntary arrangements see M. Rutstein, "Voluntary Arrangements: Contracts or Not?" [2000] 13 Ins Intell 1 and 11.

74 [1999] 1 BCLC 621. For comment see C. Berry and P.K. Su, "Voluntary Arrangements - A Question of Variation" (1999) 15 IL \& P 120; E. Bailey, "Variation of IVAs" [2000] 4 RALQ 35.

75 On this reluctance to imply terms see Re Alpa Lighting Ltd [1997] BPIR 341, and Alman v Approach Housing Ltd [2001] 1 BCLC 530. One way around this is to incorporate express terms dealing with particular contingencies but the courts have been alert to warn of the dangers that these may be too vague - see Horrocks $\mathrm{v}$ Broome [2000] BCC 257. 
July which will propose the abolition of the private remedy of administrative receivership ${ }^{76}$.

On the positive side, the changes in the ambit of the moratorium may certainly result in officially sanctioned rescue procedures appealing over other alternatives (such as receivership). The shutting out of landlords may certainly enhance the comparative attractiveness of collective rehabilitation procedures over competing insolvency regimes. But increasing the reporting/monitoring role of supervisors may have a negative impact upon the attitudes of certain debtors or certain directors of debtor companies who may have welcomed the "light touch". One change in the model may thus neutralise another.

Another thought worth considering is whether the change in the law on interest on the Insolvency Services Account for the benefit of bankrupt estates as introduced by section 13 of the Insolvency Act 2000 might in future render IVAs less financially attractive than the bankruptcy option is at present. This technical reform certainly may affect the mathematics, but the other attractions in the IVA route (such as the absence of stigma, investigation and disqualification) remain largely unaffected.

\section{CONCLUSION:}

\section{The Issue Of Debtor Rehabilitation Will Not Go Away}

Discussion of debtor rehabilitation has taken a significant step forward over the past year. Vital principles are now being articulated. Nettles are being grasped. It is apparent to all that the debate on the way forward for debtor rehabilitation has plenty of mileage left. The largest unresolved issue is the problem of financing rescues and whether a super-priority scheme should be introduced ${ }^{77}$. This is touched upon in the November 2000 Insolvency Service Report where it is recognised that more work is required on this key issue $^{78}$. There is little point in establishing a secure basis for a rescue scheme if the exploitation of that proposal cannot be financed.

A perusal of the joint DTI/ DEE Report on Opportunity for All in a World of Chang $^{79}$ provides a clear indicator of an agenda for the next Parliament. Bankruptcy will be further deregulated to promote a "fresh start" philosophy. Thus, we are told that there will be a one year period ${ }^{80}$ for discharge from bankruptcy for "honest debtors" (paragraph 5.11) and that the current practice of stigmatising bankrupts will be reviewed. Those who are deemed

76 HM Treasury Press Notice 67/01.

77 Tax debts accruing on an administration increasingly appear to enjoy this super priority under section 19 of the Insolvency Act 1986 (Art 31(5)of 1989 Order) See here IRC v Lawrence [2001] 1 BCLC 204 (PAYE and NIC due on employees' wages).

78 See paras 122-139.

79 Cm 5052, February 2001.

80 The current period for automatic discharge is three years (or two years in the case of a summary administration) - see Insolvency Act 1986 s. 279(2) (Art 253(2) of 1989 Order). In the April 2000 Insolvency Service consultation paper (A Fresh Start) a period as short as 6 months had been suggested! For criticism see footnote 30 above. 
culpable - the irresponsible, the negligent and the dishonest can look forward to a harsher climate. This is very interesting; the devil will lie in the detail. How one distinguishes between the honest debtor and the other category (which includes "irresponsible debtors") will be an interesting challenge requiring considerable legal attention. If these changes do indeed come about we will need to re-evaluate the future role (if any) of the IVA procedure; its relative attractions may not be as substantial with the advent of a more "user friendly" bankruptcy regime. Further changes in the law on corporate rescue are also alluded to in the DTI/DEE report, but the ominous phrase "as soon as Parliamentary time allows" engenders a sense of foreboding. We must remind ourselves that the ideas enacted in last year's Insolvency Act had been floated in the early part of the 1990s.

I would like to finish on a welcome note. The November 2000 Insolvency Service Report does recognise the need for further research on the operational impact of rescue procedures and for a more co-ordinated approach to Insolvency Reform through the auspices of a new Advisory Committee. The experience of the past has been one of piecemeal reform based upon a lack of empirical evidence. Things have changed over the past year and it was pleasing to see that the Insolvency Service made critical use of a number of research projects to inform their analysis in the November 2000 Report.

\section{POSTSCRIPT}

Since completing this article the government has redeemed its pledge to produce reform proposals. In Productivity and Enterprise: Insolvency - A Second Chance $^{81}$ it firmed up a number of points flagged in the HM Treasury Press Release of June 18. Administrative receivership will indeed be abolished (except in cases of enforcement of ("market changes"). The floating charge holder's right of veto over administration will be removed (with the predictable exception in the capital market context). Crown preference is to be abandoned in both corporate and personal insolvency. Honest bankrupts, whose conduct cannot be deemed "reckless", are to be given a much gentler treatment by bankruptcy law. The "post bankruptcy IVA" will be given its head and the Official Receiver allowed to compete with the private sector providers in an effort to increase competition and thereby reduce costs. These reforms are to be subjected to a period of consultation and, after reflection, enacted in a forthcoming Enterprise Bill. This is not the time to evaluate such proposals in depth, but merely to comment that they reflect the trends highlighted above.

81 Cm 5234 (July 31 2001). 